\title{
ECONOMETRIC ANALYSIS FOR TOURISM DEMAND FUNCTION IN EGYPT: A DYNAMIC PANEL DATA APPROACH
}

UDC 338.482:303.4(620)

\section{Waleed Said Soliman Faragalla}

\author{
Faculty of Commerce, Menoufia University, Menoufia, Egypt
}

\begin{abstract}
In this paper, the author investigates the tourism demand function using the dynamic panel data approach in the case of Egypt. The panel data set covers the time period between 1995 and 2014. The individuals are 49 countries as origin countries for tourists, representing $92 \%$ of the total tourist arrivals to Egypt. Explanatory variables which affect the tourism demand function were taken into account: lag of dependent variable that leads to dynamic panel data approach, using DIFF-GMM estimator proposed by Arellano and Bond (1991); also, many other explanatory variables like GDP per capita, relative price index, distance, and dummy variable which represent the political situation. One of the important and significant conclusions of the paper is the significant effect of the lagged dependent variable (0.493), which may be explained as "Word of Mouth" to tourists' decision when choosing the destination.
\end{abstract}

Key words: dynamic panel data, tourism demand, DIFF-GMM, Egypt

JEL Classification: C15, C 51, C33, Z32

\section{INTRODUCTION}

The tourism in Egypt has a significant role in Egyptian economy, and the tourism development has a vital contribution in economic and social development. As the fastestgrowing and the largest industry in the world, according to World tourism organization, and the industry with the largest number of employees, it contributes to the increasing standard of living. Thus, the state is interested in tourism development and ready to support it with large investments due to its impact on the GDP increase, taxes, capital investment and value added. Furthermore, tourism is the most important source of welfare in many regions and countries.

Received October 11, 2016 / Revised August 15, 2017 / Accepted August 31, 2017

Corresponding author: Waleed Said Soliman Faragalla

Faculty of Commerce, Menoufia University, Menoufia, Egypt

${ }^{*} \mathrm{PhD}$ candidate at Faculty of economics, University of Belgrade, Belgrade, Serbia

E-mail: waleedsaid17@gmail.com 
According to the World tourism organization in 2004, the number of tourist arrivals to Egypt was around 8.1 million, bringing around US\$ 6.3 billion of Gross Domestic Product. By 2010, both the number of arrivals and GDP nearly doubled, the number of arrivals increased to 14.73 million, and tourism contribution to GDP grew to US\$13.63 billion. In addition, the contribution of the travel and tourism industry in total employment was about 1,744 million jobs. However, the political situation in Egypt in 2013 clearly affected the number of tourist arrivals in Egypt, leading to the decrease in the number of arrivals to 9.46 million, accounting for US\$ 6.75 billion within GDP. This paper analyzes the relationship between the demand tourism in Egypt and other economic variables which affect the demand tourism function, such as Gross Domestic Production, the relative price between the host country and the origin countries, the distance between Egypt and these countries. The paper will also cover non-traditional factors including geographical location, whether the countries have a common border, the number of World Heritage sites, the time zone difference, and the political situation in Egypt as dummy variables. Many scientific papers investigated this relationship in many countries such as Turkey, Portugal, Austria, Germany and Malaysia. However, this paper will be the first to investigate this relationship using the dynamic panel data model depending on GMM-DIFF approach in the case of Egypt. The main contributions of this paper can be found in estimating the variables which are included in the tourism demand model in Egypt using the suggested GMM -DIFF methodology.

Specifically, in the case of Egypt tourism should be studied as the pivotal part of economy, since as a destination it is the place of the oldest civilization, with pleasant weather throughout the year. Tourists come to Egypt all year round: in the summer, the main destinations are cities like Alexandria, Hurghada, Sharm El Sheikh, and Marsa Matrouh, while in the winter, tourists can come to cities like Luxor and Aswan. Throughout the year, historical places like the Egyptian museum, the pyramids and the sphinx in Cairo and Giza are available for visits. Egypt supports many types of tourism such as medical tourism, educational tourism (conferences), and religious tourism. Also, there are many Christian monasteries and Islamic places and the safari in the beautiful area of St. Catherine, Mount Moses in Sinai, Al-Dakhlah and AI-kharg, where tourists can watch different animals and migrating birds.

The purpose of this study is to empirically cover the weaknesses observed in the research of the demand function of tourism in Egypt, especially by using dynamic panel data. More specifically, this paper is the first one to use the approach of studying the demand function of tourism using dynamic panel data models based on GMM -DIFF in Egypt. Additionally, the dynamic estimation approach is used to investigate the long-term tendencies of tourism movements in Egypt.

This paper investigates the effects of various factors on the dynamics of tourism demand in Egypt. Because of that, we use econometric methodology by applying Generalized Method of Moment estimator (GMM-DIFF) on the dynamic panel data model. Especially, there are few studies using dynamic panel data analysis in tourism in Egypt. The importance of this study lies in the utilization of the panel data model from 1995 to 2014, which allows the estimation of the effect of different variables on the tourism demand in Egypt, with more information from cross section data and time series analysis. Although these approaches were applied in many different studies, the estimated elasticities change from one country to another and from period to period, depending on the explanatory variables. The paper is organized as follows: After the introduction, a literature review of empirical studies in the field of tourism is given in Section 2. Section 3 is dedicated to the 
econometric estimation methods of dynamic panel data models, while Section 4 contains the main estimation results. Further discussion and conclusion are presented in Section 5.

\section{LITERATURE REVIEW}

During the last two decades, there was a growing empirical literature on tourism modeling focused on the determinants of the tourism demand and especially on prediction of the tourist demand. Variables included in the tourism demand models differ from paper to paper. The dependent variable, the demand of tourism, is represented as the number of tourist arrivals, number of overnights, or the revenue of tourism from tourists (Song and Li, 2008). When it comes to independent variables, many of them were used in different analyses on the tourism demand model. Most common variables are the lagged variable of dependent variable, average income per person in other countries, the cost of traveling, the government expenditure in tourism and marketing, and price of tourism (Song and Li, 2008). In (Sara A. Proença and Elias Soukiazis; 2005), the authors divided the independent variables in two groups: the first group incorporates demand factors such as real personal income and the relative price of tourism, while the second group represents supply factors such as the number of beds in hotels available for tourists, the infrastructure in the hosting country.

Various econometric techniques are used to estimate the tourism demand function. According to applied methods, the mentioned literature could be divided into three groups. The papers in the first group used the technique of cross section data and classical multiple regression (for example, Witt and Witt, 1995; Lim, 1997 and 1999; Crouch, 1994 and 1995). The second group of empirical studies used modern time series data technique and cointegration (for example, Kulendran and Witt, 2001; Song et al. 2003; Narayan, 2004; Drivisekera, 2007; Ouerfelli, 2008). Finally, the third group of studies makes a combination between cross section data and time series data in tourism demand using panel data regressions and different estimation methods (Generalized least squares method (GLS) like Naude and Saayman (2005), Generalized method of moment (GMM), etc.).

The problem of biased estimates when the lagged dependent variable is one of the explanatory variables is considered by Sequeira and Nunes (2008). They investigate the effect of country risk on tourism demand using generalized Method of Moment (systemGMM) with dynamic panel approach, finding the significant statistical effect for variables of the natural logarithm of tourism specialization, as well as prices. In addition, Teresa and Martin (2007) investigate the determinants of tourist arrivals to the Balearic Islands for the period 1991-2003 from the 14 major origin countries using the panel data approach. The result of their model showed that the lagged dependent variable of the number of tourists is significant as well as the relative price, at 0.05 significance level; however, the variable gross domestic product was not significant.

A different study, conducted by Munoz (2007), estimates the impact of Germany tourism demand in Spain for the period 1991-2003, using the dynamic panel data. This study aimed to prove that lagged tourism arrivals present a positive effect in the long run. The result showed that the Portuguese economy charges higher prices and these are associated with high quality products. The coefficient of government spending (GOVSP) is statistically significant at $1 \%$ level. Government expenditures are important for attracting the tourists to a destination. The significance effect for lagged dependent variable at 0.05 significance level was also found. 
Building on the same idea, Skrinjaric (2011) analyzes the tourism demand in Croatia for the period from 1994 to 2009 for 19 partners. He utilizes a GMM-system, explaining that the variation in tourism demand depends on the ICP and income per capita. In 2014, Serra et al, studied a similar problem in Portugal in the period between 2000 and 2011, covering seven regions in Portugal. While recognizing the positive sign for the variables demonstrated in the research, the authors found the significance effect for the variable real per capita income of the sending country, as well as public investment ratio in the host country at 0.05 significance level. Recently, Zhang (2015) investigated the explanatory variables for the period 2009- 2013 for the sample covering 40 countries using dynamic panel (GMM-system). The model shows that the jet fuel price has no significant impact on the number of inbound travelers, but the variable of the gross domestic product (GDP) is significant at 0.1 significance level.

Following the majority of the literature, we can also use the dynamic panel data specification and methods like Arellano-Bond first-step GMM estimator to investigate the determinants of tourist arrivals.

\section{ECONOMETRIC METHODOLOGY FRAMEWORK}

The difference and system generalized method-of-moments estimators, developed by Holtz-Eakin, Newey, and Rosen (1988); Arellano and Bond (1991); Arellano and Bover (1995); and Blundell and Bond (1998) are increasingly popular. Those estimation methods can be used when independent variables are not strictly exogenous. Namely, when they are correlated with past and possibly current realizations of the error term. System of equations in both first-differences and levels, where the instruments used in the levels equations are lagged first-differences of the series. These instruments are valid under restrictions on the initial conditions, to obtain a linear GMM estimator better suited to estimating autoregressive models with persistent panel data.

There are many advantages of using GMM-DIFF such as efficiency, weighted by the inverse of the variance of the population moments, which, under suitable conditions, is the asymptotic variance of the sample moments. The second advantage is feasibility, meaning that making GMM practical requires a feasible estimator for the optimal weighting matrix. There is also a disadvantage of difference and system GMM is that they are complicated and so can easily generate invalid estimates.

In this study, a dynamic panel data (GMM-DIFF) will be used. This estimator helps the researchers to solve the problems of serial correlation, heteroskedasticity and endogeneity for some explanatory variables. The GMM-System estimator is an alternative to the standard first differenced GMM estimator, suitable for estimating the dynamic model. Arellano Bond estimation starts with the difference GMM by transforming all regressors, usually by differencing. After that, it uses the Generalized Method of Moments, thus called "difference GMM". Forward orthogonal deviations transform, proposed by Arellano and Bover (1995) is sometimes performed instead of differencing. The Arellano-Bover/Blundell-Bond estimator augments Arellano-Bond by making an additional assumption. The GMM-DIFF estimator is consistent if there is no second-order serial correlation in the residuals. However, that first differences of instrumental variables are uncorrelated with the fixed effects; the dynamic panel data model is valid if the estimator is consistent and the instruments are valid. 
There are also assumptions about the data generating process for the difference and system GMM estimators when we design panel analysis: the process and data may be in dynamic type, with current realizations of the dependent variable influenced by past ones (lagged dependent variable); some regressors may be endogenous, and/or predetermined (not strictly exogenous).

The construction of the panel data model with lagged dependent variables as one of explanatory variables, the unobserved panel-level effects are correlated with the lagged dependent variables, thus making standard estimators inconsistent. Arellano and Bond (1991) derived and introduced consistent generalized method of moments (GMM) estimator for this model. Moreover, this estimator is designed for datasets with many (N) and few (T). This method assumes that there is no autocorrelation, and requires the initial condition that the panel-level effects is uncorrelated with the first difference of the first observation of the dependent variable.

Special interest in statistical inference is post estimation procedure for the method (GMMsystem). Firstly, the Arellano-Bond test for serial correlation in the first-differenced residuals should be applied (command in STATA estatbond). The estimation by GMM-DIFF is valid only if there is no serial correlation in the idiosyncratic errors. If the Arellano-Bond test rejects the null hypothesis of no serial correlation in the first-differenced errors at order one, it does not imply that the model is miss specified. However, rejecting the null hypothesis at higher orders implies that the moment conditions are not valid. Secondly, the Sargan tests the overidentifying restrictions (command in STATA estat sargan). The moment conditions used by GMM-DIFF can produce consistent estimates only if the moment conditions used are valid. Although there is no method to test if the moment conditions from an exactly identified model are valid, one can test whether the overidentifying moment conditions are valid.

\section{EMPIRICAL ANALYSIS OF TOURIST DEMAND IN EGYPT}

\subsection{Econometric model and data}

The methodology of this paper will be dynamic panel data estimation methods, as often used in the previous empirical literature. This approach will be used to evaluate the demand function of tourism in Egypt during the 20-year-period from 1995 to 2014 in relation with eighteen countries, which represent around $92 \%$ of the annual number of tourist arrivals in Egypt: the Russian Federation, the United Kingdom, Germany, Italy, Saudi Arabia, Poland, the Sudan, the United States of America, Jordan, Libya, Canada, China, Denmark, Sweden, Austria, Belgium, France, and the Netherlands. These countries have been chosen as the biggest contributors to the number of tourists who come to Egypt yearly.

There are many advantages of panel data analysis over the cross-section data or time series data alone: it enables higher degree of freedom, and higher variability which consequently decrease the multicollinearity between variables (Hsiao, 2003). This makes the parameters more accurate and gives us the ability to control for omitted variable bias. Using dynamic panel data approach instead of static regression is convenient, as the later one has many problems such as instability (Witt and Song, 2000). In this paper, the dependent variable will be the number of tourists based on the data from the formal statistical source, United Nation World Tourism Organization (UNWTO). In this paper, variables will be as follows: 


\subsection{Variables:}

\section{Dependent variable: $\mathbf{N T}_{\mathrm{it}}$}

Number of tourists $\left(\mathrm{NT}_{\mathrm{it}}\right)$ : this variable represents the number of tourists arriving to Egypt from origin countries such as: the Russian Federation, the United Kingdom, Germany, Italy, Saudi Arabia, Poland, the Sudan, the United States of America, Jordan, Libya, Canada, China, Denmark, Sweden, Austria, Belgium, France, and the Netherlands, during the period from 1995 to 2014, based on the data from the UNWTO.

\section{Independent (explanatory) variables:}

1. Lagged Number of tourists $\left(\mathrm{NT}_{\mathrm{it}-1}\right)$ : this variable represents the number of tourists arriving to Egypt from different countries (i) during the previous years (t-1). The expected sign for this variable is positive, due to the habit and preference of the tourists to go to the same place again.

2. GDP per capita $\left(\mathrm{GDPPC}_{\mathrm{it}}\right)$ for sending countries: represents the gross domestic product per capita for each of the different countries (current US\$), sourced from the World Bank site, the expected sign for this variable is positive.

3. Relative price index $\left(\mathrm{p}_{\mathrm{it}}\right)$ : represents the relative price index between the hosting country and the sending countries, in precise the Consumer Price Indexes in Egypt and the sending countries. This variable is given by the ratio of the price index level of the receiving country (Egypt) and the sending country, adjusted by the bilateral exchange rate. The source of that variable is calculated via formula based on the data from the World Bank. The expected sign for this variable is negative.

$$
p_{i t}=\frac{C P I_{\text {Egypt }}}{C P I_{\text {Sending countries }} E R_{i t}}
$$

4. Distance $\left(D_{i t}\right)$ : the geographical distance between Egypt and sending countries represent a significant proxy for the cost, paid by tourists to arrive to Egypt. The distance will be measured by kilometers between cities, via website www.distancefromto.net.

5. Dummy variables: reflect the political situation in Egypt, presence of violence and terrorism. This variable is very important, as tourists tend to investigate the political situation before going to any hosting country. This variable takes value one when the situation in Egypt is unstable. The variable is based on the political analysis literature in Egypt, and it depends on the political situation between 2011 (January), when there was a revolution, and 2013 (June), when we got a new president. In this period, many of foreign embassies issued warnings for their host countries, advising against visiting Egypt in this period, such as Germany, France, Italy and Israel. Thus, the dummy variable was divided to three variables for the years 2011, 2012, and 2013:

When year 2011 is dummy variable which takes unity (1) for the year 2011, zero otherwise, year $_{2012}$ is dummy variable which takes unity (1) for the year 2012, zero otherwise. If Egypt has a bad political security in year 2012 and takes zero for other years, year 2013 is dummy variable which takes unity (1) for years 2013 , zero otherwise. 


\section{Non-traditional factors:}

These variables are non-traditional variables in previous models, incorporated in our model to explore their effect on the tourism demand function in Egypt. There are some that have natural candidate which may have a significant impact on the tourism demand function. Dummy variables will be used for each of these variables to check if there is significance relation on the tourism demand function or not. The source for these variables is available by world development indicators, for instance:

1. Geographical location (GL), means countries have the same border. This variable represents the countries which have a common border with Egypt, and the effect of the common border can be estimated in the model. GL is dummy variable which takes unity (1) if the sending country has the same border with Egypt, zero otherwise.

2. Number of World Heritage sites (NHS):

The variable tests the estimation of the difference of the world cultural and natural Heritage sites in the sending countries and destination country, the tourists can prefer to visit the country with more cultural and natural Heritage sites, they may be interested in discovering different and heritages abroad, the data of this variable available on UNESCO site (Culiuc, 2014).

$\mathrm{NHS}_{\mathrm{it}}=\left(\right.$ cultural and natural Heritage sites in sending countries) ${ }_{\mathrm{t}}-($ cultural and natural Heritage sites in Egypt $)_{\mathrm{t}}$

3. Time zone difference (TZD): the difference in time zone represents an important variable in tourism demand function, the tourism decreases in case of big difference between the sending and hosting countries. $\mathrm{TZD}_{\mathrm{i}}$ is the time difference in hours between the sending countries and hosting country (Egypt).

4. Common language (CL): similarly, to the trade, the common language plays an important role in increasing number of tourists, especially in communication between the countries. CL is dummy variable which takes unity (1) if the sending country has the same language as Egypt, zero otherwise.

The econometric panel data model of tourism demand in our empirical analysis contains the following explanatory variables:

$N T_{i, t}=f\left(N T_{i, t-1}, G D P P C_{i, t}, P_{i, t}, D_{i, t}\right.$, year $_{2011}$, year $_{2012}$, year $\left._{2013}, D G L_{i, t}, C S I_{i, t}, N H S_{i, t}, T Z D_{i, t}, C L_{i, t}\right)(1)$

The tourism demand estimated model is in the double-logarithmic form, as the most recommend form in previous empirical literature. Witt and Witt (1995) concluded that more than $75 \%$ of the empirical econometric models were designed in that functional form are easy for the interpretation of the coefficients through the demand elasticity. The parameter $\beta 1$ indicates to what degree is the tourism demand in Egypt affected by the number of previous tourist arrivals. Thus, econometric model for estimation has the following form:

$\ln N T_{i, t}=\beta_{0}+\beta_{1} N T_{i, t-1}+\beta_{2} \ln G D P P C_{i, t}+\beta_{3} \ln P_{i, t}+\beta_{4} \ln D_{i, t}+\beta_{5}$ year $_{2011}+\beta_{6}$ year $_{2012}+\beta_{7}$ year $_{2013}+$ $\beta_{8} D G L_{i, t}+\beta_{9} C S I_{i, t}+\beta_{10} N H S_{i, t}+\beta_{11} T Z D_{i, t}+\beta_{12} C L_{i, t}+\gamma_{t}+\mu_{i}+\varepsilon_{t}$

With $\mathrm{i}=1,2, \ldots, 20$ and $\mathrm{t}=1,2, \ldots, 49$.

when: $V_{i t}=\gamma_{t}+\mu_{i}+\varepsilon_{i t}, V_{i t}$ is the fixed effects, $\mu_{i}, \gamma_{t}$ are country effect and time effect respectively. $\varepsilon_{i t}$, which is the error term, should be serially uncorrelated with zero mean, 
and independently distributed across individuals. It also has to be uncorrelated with the dependent variable for all $\mathrm{t}$.

Because of the dynamic processing in the model, it will face a problem of correlation between the first explanatory variable (lagged dependent variable) and the error term. So that, if we used the fixed effect (OLS) or random effects (GLS), our estimated coefficient would not be efficient, and it would be biased estimator. To override this, Generalized Method of Moment (GMM) estimation will be used to estimate dynamic panel data (Arellano and Bond, 1991), however assuming that there is no second-order autocorrelation in the errors. The main advantage of using GMM estimate lies in the control of the endogeneity through the lagged values of the levels of the endogenous, while the predetermined variables are instruments. The best solution for this problem is to use the first difference for the equation (2) to remove the individual effects followed by using the instrumental variables using instruments the values of the lagged two or more for dependent variable. This solution will offer consistent parameter but not efficient, provided by the first difference GMM method offered by Arrelano and Bond (Arrelano and Bond 1991, Hsiao 2003). This method assumed that there is not second autocorrelation in error term, and the equation will be offered as following:

The dynamic panel data model will be formulated as following: $\Delta \ln N T_{i, t}=$ $\beta_{1} \Delta \ln N T_{i, t-1}+\beta_{2} \Delta \ln G D P P C_{i, t}+\beta_{3} \Delta \ln P_{i, t}+\beta_{4} \Delta \ln D_{i, t}+\beta_{5} \Delta$ year $_{2011}+\beta_{6}$ yyear $_{2012}+\beta_{7} \Delta$ year $_{2013}+$ $\beta_{8} \Delta D G L_{i, t}+\beta_{9} \Delta C S I_{i, t}+\beta_{10} \Delta N H S_{i, t}+\beta_{11} \Delta T Z D_{i, t}+\beta_{12} \Delta C L_{i, t}+\Delta \varepsilon_{t}$

With $\mathrm{i}=1,2, \ldots, 20$ and $\mathrm{t}=1,2, \ldots, 20$.

$\Delta \ln N T_{i, t}=\ln N T_{i, t}-\ln N T_{i, t-1}$ And the same for all other variables, with method assuming that there is no second autocorrelation in error term, and Sargan model of overidentifying restrictions, as soon as we cannot reject the null hypotheses gives strength to the model.

\section{EMPIRICAL RESULTS}

\subsection{Descriptive analysis}

The following section describes the characteristics of the number of tourists in Egypt during the period from 1995 to 2014 . The number of tourists increased continuously until its peak in 2010, at approximately 14.7 million tourists. After that, due to increasingly unstable political situation in Egypt, a drop is visible in 2011 and 2013 to below 10 million arrivals.

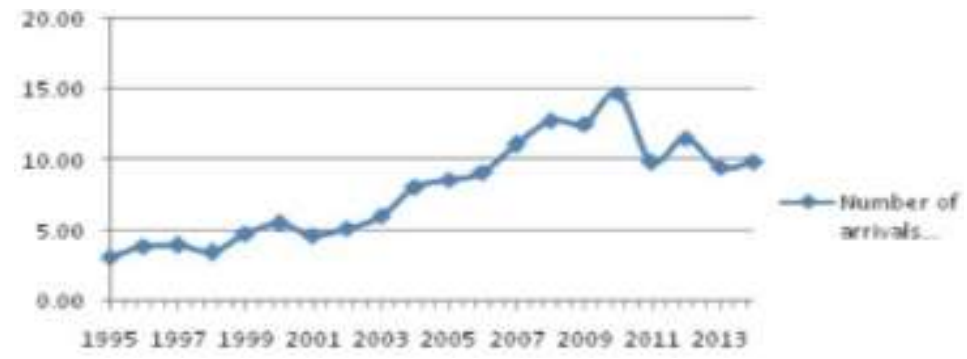

Graph 1 Total number of tourists 1995 -2014

Source: United nation world tourism organization (UNWTO) 
The following table represents the percentage of the total number of arrivals for each country, across the years 1995, 2000, 2005, and 2010.

Table 1 Origin of the tourists in Egypt 1995, 2000, 2005, 2010, and 2014 (In percentage of total number)

\begin{tabular}{lrrrrr}
\hline Year & \multicolumn{1}{c}{1995} & 2000 & 2005 & 2010 & 2014 \\
\hline Russian Federation & 3.51 & 3.30 & 9.03 & $\mathbf{1 9 . 3 9}$ & $\mathbf{3 1 . 7 8}$ \\
United Kingdom & 9.08 & 6.52 & 9.73 & 9.88 & 9.17 \\
Germany & 10.19 & 14.28 & 11.38 & 9.02 & 8.88 \\
Italy & 8.21 & 13.66 & 9.56 & 7.77 & 4.05 \\
Saudi Arabia & 5.73 & 4.36 & 4.20 & 2.55 & 3.54 \\
Poland & 0.54 & 1.04 & 1.79 & 4.03 & 3.07 \\
Sudan & 1.47 & 0.96 & 1.32 & 1.29 & 1.89 \\
United States of America & 4.94 & 4.27 & 2.27 & 2.45 & 1.57 \\
Jordan & 1.57 & 1.43 & 1.46 & 1.16 & 1.73 \\
Libya & 5.01 & 2.77 & 4.37 & 3.06 & 2.14 \\
Canada & 0.83 & 0.84 & 0.61 & 0.65 & 0.55 \\
China & 0.19 & 0.25 & 0.41 & 0.72 & 0.62 \\
Denmark & 0.63 & 0.93 & 1.07 & 0.92 & 0.54 \\
Sweden & 0.62 & 1.27 & 1.42 & 1.43 & 0.55 \\
Austria & 1.10 & 1.81 & 1.59 & 1.63 & 1.32 \\
Belgium & 1.43 & 1.94 & 1.79 & 1.33 & 0.75 \\
France & 3.90 & 6.90 & 5.75 & 4.07 & 1.47 \\
Netherlands & 1.25 & 2.58 & 2.39 & 1.98 & 1.28 \\
\hline Total percentage & 60.19 & 69.11 & 70.16 & 73.33 & 74.89 \\
\hline
\end{tabular}

Source: United nation world tourism organization (UNWTO)

The main aim of this work is to explore the international demand which represents $73 \%$ of all tourist arrivals, with a total of almost 15 million foreign tourists in 2010 . The previous table represents the percentage of the number or the arrivals for each country, in five years. Germany leads with the highest percentage in 1995, 2000, and 2005, which are 10\%, 14\%, and $11 \%$ respectively. However, the Russian Federation represents the highest percentage in 2010 , and 2014 with $14 \%$ and $32 \%$ respectively. The listed countries jointly represent $70 \%$ of the total number of tourists in Egypt in 2005, increasing to 75\% in 2014.

\subsection{Econometric methodology}

The value of studying tourism demand models planning and policy has been discussed widely in many studies using the traditional regression model. However, those studies concentrated on static models which had many problems, including forecasting failures. In order to answer this problem, we will use Generalized Method of Moment estimation (GMM), developed by Arellano and Bond (2002) and used to estimate dynamic panel data (in STATA V.12). The lagged dependent was used as the explanatory variable, in order to capture the persistence effects of the tourist's habits and behavior. Two main reasons for using the lag variables number of tourist arrivals in Egypt are: firstly, uncertainty: there is strong certainty associated with visiting the country that you know and are familiar with it, contrary to visiting a country for the first time. Secondly, "the word of mouth" or spreading 
other people's knowledge and experience about the beauty of a destination and comparativeness of the country, depending on many variables like the level of education, infrastructures, number of old heritage sites and many other variables. From that dynamic specification Eq (3), the result will be as follows:

Table 2 Estimation results for the linear and dynamic model (1995-2014)

\begin{tabular}{lrc}
\hline Variables & GMM DIFF estimator of Arellano and Bond \\
\hline Constant & -15.847 & $(0.254)$ \\
ln_LagNT & $\mathbf{0 . 4 9 3}$ & $\mathbf{( 0 . 0 0 0 )}$ \\
ln_GDPPC & $\mathbf{0 . 5 3 3}$ & $\mathbf{( 0 . 0 0 0 )}$ \\
ln_distance & 1.996 & $(0.247)$ \\
ln_relativeprice & -0.009 & $(0.483)$ \\
year2011 & $\mathbf{- 0 . 4 5 8}$ & $\mathbf{( 0 . 0 0 0 )}$ \\
year2012 & $\mathbf{- 0 . 0 9 0}$ & $\mathbf{( 0 . 0 1 7 )}$ \\
year2013 & $\mathbf{- 0 . 4 1 1}$ & $\mathbf{( 0 . 0 0 0 )}$ \\
TZD & 0.254 & $(0.419)$ \\
Number of observation & 882 & \\
Wald hi2(8) & 3054.22 & $(0.000)$ \\
Sargan chi (189) & 94.11 & $(0.875)$ \\
\hline
\end{tabular}

The bold numbers are significant at 0.05 significance level.

The equation will be as following:

$\ln N T_{i, t}=-15.847+0.493 \ln N T_{i, t-1}+0.533 \ln G D P P C_{i, t}-0.009 \ln P_{i, t}+1.996 \ln D_{i, t}-$ 0.458 year $_{2011}-0.090$ year $_{2012}-0.411$ year $_{2013}+0.254$ TZD $_{i, t}$

Number of observation $=882$, Wald $\operatorname{chi}(8)$ test $=615.73$, Sargan $=94.11(0.875)$.

Table 2 represents the estimated equation for the tourism demand function in Egypt using dynamic panel data when the $\mathrm{i}$ (individuals) is defined as the number of countries from 1 to 49, and the $\mathrm{T}$ defined as the number of years from 1995 to 2014. Based on the Arellano and Bond method we had the following estimated function:

From the previous equation, the value of Sargan test statistic has value 94.11 and $p$ value 0.875 , meaning that the test is not significant and the null hypothesis saying that the instruments used in this regression are correct can be accepted. Furthermore, the coefficient of lagged dependent variable ( $\ln \mathrm{NTi}_{\mathrm{t}-1}$ ) is significantly estimated in the equation. That means, it is the behavior and habit (Word of mouth) for tourists to come to Egypt, and this result supports using demand is a dynamic process, confirming the previous studies which also found positive effect for this variable (Serra et al, 2014; Rodríguez et al, 2015).

The second explanatory variable is GDPPCA, also statistically significant with a positive sign, showing that there is a statistically significant relationship between the Gross domestic product per capita in sending countries and the number of tourists from these countries, the Relative price (pit), defined as the relative price index between the hosting country and the origin countries with respect to the Exchange rate, also dummy variables are statistically significant, they represent the political situation in Egypt in 2011, 2012 and 2013 , there is negative significant relationship between the number of tourists and dummy variables which represent the years 2011, 2012 and 2013. In these years, there were two revolutions in Egypt in the period between 2011 and 2013. However, other variables are not statistically significant. 


\section{CONCLUSION AND DISCUSSION}

The main aim of this paper is to identify and estimate the impact of the explanatory variables in the tourism demand function in Egypt from other countries such as Russia, Germany, Italy, the United Kingdom, France, Libya, Saudi Arabia, and Israel, and other countries which contribute mostly to the total number of tourist arrivals representing $92 \%$ of the total number every year, by using dynamic panel data during the period from 1995 to 2014, by using STATA v.12 depending on GMM-DIFF method which is presented by Arellano and Bond (1991) for analyzing dynamic panel data models.

By comment for the estimated elasticity in our model, we obtained the positive sign for the lagged variable of the number of tourists, and GDPPC in this country, and the values are lower than one and with the positive sign (0.493), and (0.533) respectively. However, we have the negative sign for dummy variables 2011, 2012 and 2013, as follows, (0.458), (0.090) (0.411) respectively. The tourism in Egypt is considered to be a non-luxury service by foreigners. For other variables, which represent the relative price, the distance between countries, and a different time zone between Egypt and other countries, the model returned non-statistically significant results. This study can recommend to the decision makers in Egypt to put priority on investment in the tourism sector such as investments in infrastructures, communication, increasing number of rooms, which would further lead to increasing the number of tourists sending countries. Egypt has to invest money in this important sector, especially towards those countries, as they represent a large percentage of the total number of tourist arrivals in Egypt.

\section{REFERENCES}

Arellano, M. \& Bond, S.R. (2007). Dynamic Panel GMM Estimators in Stata Tutorial with Examples Using Stata 9.0 (Xtabond And Xtabond2) Elitza Mileva, Economics Department Fordham University.

Arellano, M. \& Bond, S.R. (1991). Some Tests of Specification for Panel Data: Monte Carlo Evidence and An Application to Employment Equations. Review of Economic Studies 58, 277-297.

Aslan, A., Kaplan, M. \& Kula, F. (2008). International Tourism Demand for Turkey: A Dynamic Panel Data Approach. Munich Personal REPEC Archive, Paper No. 10601

Blundell, R., \& Bond S. (1998). Initial conditions and moment restrictions in dynamic panel data models. Journal of Econometrics 87: 115-143.

Brida.J.G. \& Risso, W.A (2009). A Dynamic Panel Data Study of the German Demand for Tourism in South Tyrol, Tourism and Hospitality Research.

Brida.J.G.\& Risso, W.A (2009), A Dynamic Panel Data Study of the German Demand for Tourism in South Tyrol, Tourism and Hospitality Research, http://dx.doi.org/10.1057/thr.2009.15

Crouch, G. (1994a). The Study of International Tourism Demand: A Survey of Practice, Journal of Travel Research, 22, 41-57.

Crouch, G.I (1995). A Meta-Analysis of Tourism Demand, Annals of Tourism Research, 22, 103-118.

Culiuc, A. (2014). Determinants of International Tourism. International Monterey Fund, IMF Working Paper No. $14 / 82$

Eugenio-Martín, J. L., Morales, N.M. \& Scarpa, R., (2004). Tourism and Economic Growth in Latin American Countries: A Panel Data Approach, International Conference on Tourism and Sustainable Economic Development - Macro and Micro Economic Issues Held in Sardinia, Italy.

Habibi, F. \& Hossein, H. (2011). Dynamic Panel Data Analysis of European Tourism Demand in Malaysia, Iranian Economic Review, Vol.15, No.29, Spring 2011.

Hansen, L.P. (1982). Large Sample Properties of Generalized Method of Moments Estimators, Econometrica, 50: $1029-1054$.

Leitão, N.C. (2015). Portuguese Tourism Demand: A Dynamic Panel Data Analysis, International. Journal of Economics and Financial Issues, 2015, 5(3), 673-677. 
Li, G., Wong, K. F., Song, H. \& Witt, S. F. (2006). Tourism Demand Forecasting: A Time Varying Parameter Error Correction Model, Journal of Travel Research, 45, 175-185, http://dx.doi.org/10.1177/0047287506291596

Lim, C. (1999). A Meta-Analytical of International Tourism Demand, Journal of Travel Research, 37, $273-284$.

Munoz, T.G. \& Martin L.F., (2007). Tourism in The Balearic Islands: A Dynamic Model for International Demand Using Panel Data, Tourism Management, 28, 1224-1235.

Paulo, M., \&Tiago N. (2008). Does Country Risk Influence International Tourism? A Dynamic Panel Data Analysis. The Economic Record, Vol. 84, No. 265, June 2008, 223-236, http://dx.doi.org/10.1111/j.14754932.2008.00464.x

Sara A. Proença \& Elias, S. (2005). Demand for Tourism in Portugal: A Panel Data Approach Centro De Estudos da União Europeia (Ceuneurop), Faculdade De Economia da Universida de Coimbra.

Serra, J., Correia, A. \& Rodrigues, P.M.M. (2014). A Comparative Analysis of Tourism Destination Demand in Portugal. Journal of Destination Marketing \& Management, 2, 221-227, http://dx.doi.org/10.1016/ j.jdmm.2013.10.002

Skrinjaric, T. (2011). Investigation of Foreign Tourism Demand in Croatia Using Panel Data Analysis. Acta Turistica, 23(2), 105-238.

The Egyptian Cabinet, Information Decision Support Center (IDSC), Report About Tourism Year (8), Number (74), 2014

Witt, S.F. \& Witt C.A. (1995). Forecasting Tourism Demand: A Review of Empirical Research', International Journal of Forecasting, 11, 447-475.

Zhang, Y. (2015). International Arrivals to Australia: Determinants and The Role of Air Transport Policy. Journal of Air Management, 44-45, 21-24 http://dx.doi.org/10.1016/j.jairtraman.2015.02.004.

\section{EKONOMETRIJSKA ANALIZA FUNKCIJE TURISTIČKE POTRAŽNJE U EGIPTU: DINAMIČKI MODEL PANEL PODATAKA}

U ovom radu autor istražuje funkciju turističke pittance koristeći dinamički model panel podataka na primeru Egipta. Panel podaci obuhvataju vremenski period između 1995. i 2014. godine, a pojedinci su 49 zemalja iz kojih dolaze turisti, što predstavlja 92\% ukupnog broja turista u Egiptu. Uzete su u obzir neke objašnjavajuće varijable koje utiču na funkciju turističke potražnje: vremenski pomak zavisne varijable koja je bila razlog korišćenja dinamičkog modela panel podataka, upotrebom DIFF-GMM procenitelja koji su predložili Arelano i Bond (1991); kao i mnoge druge objašnjavajuće varijable kao što su BDP po glavi stanovnika, indeks cena, udaljenost, $i$ "dami” varijable koje predstavljaju političku situaciju. Jedan od važnih i značajnih zaključaka rada je veliki uticaj zavisne varijable sa vremenskim pomakom (0,0493), koja se može objasniti kao usmena preporuka turistima prilikom izbora destinacije.

Ključne reči: Dinamički panel podaci, Turistička potražnja, DIFF-GMM, Egipat 